\title{
Supervision of the Environmental Service of Central Sulawesi Province in Waste Management Undata Palu Hospital
}

\author{
Fatmasari Said ${ }^{1}$, Muhammad Basir-Cyio ${ }^{2}$, Nawawi Natsir ${ }^{3}$ \\ ${ }^{I}$ Social Science Study Program Postgraduate Doctoral Program, Tadulako University, Palu-Central Sulawesi, Indonesia \\ ${ }^{2}$ Faculty of Agriculture, Tadulako University, Palu-Central Sulawesi, Indonesia \\ ${ }^{3}$ Faculty of Social and Political Sciences, Tadulako University, Palu-Central Sulawesi, Indonesia
}

\begin{abstract}
This study aimed to determine the supervision of the Environmental Service of Central Sulawesi Province in managing waste at Undata Palu Hospital. This type of research is descriptive, with the number of informants as many as 13 people, which is determined using the purposive technique. The data analysis method uses three steps: data condensation, presenting data (data display) and drawing conclusions or verification (conclusion drawing and verification). Based on the results of the study, it was concluded that the supervision of hospital waste management by the Central Sulawesi Environmental Service had not run optimally, this was due to the limited number of human resources, and the competence of the supervisory officers from the Central Sulawesi Environmental Service was still limited. In terms of the equipment owned by the Central Sulawesi Environmental Service, the laboratory equipment for testing the validity of the data is still incomplete and operational vehicles are still limited in number and the lack of budget owned by the Central Sulawesi Environmental Service because each year the budget obtained is still minimal. Schedule The implementation of control carried out by the Central Sulawesi Environmental Service is still not optimal, where in the last three years, regular (scheduled) monitoring has no longer been carried out, only reports in the form of documents on the implementation of environmental management are used as a reference for the Environment Agency in monitoring The performance of hospitals in managing their waste, this happened because after the disaster that hit Palu City at the end of 2018 ago, the implementation of supervision could not be carried out maximally, because the activities of institutions, both hospitals and the Environmental Service, were still focused on improving the facilities and infrastructure of the agency.
\end{abstract}

Keywords: Supervision, Waste Management, Hospital.

\section{INTRODUCTION}

$\mathrm{W}$ aste originating from hospitals is one of the potential sources of pollution. This is because hospital waste contains high organic compounds and may contain other chemical compounds and pathogenic microorganisms that can cause disease in the surrounding community. Because the impact of hospital wastewater on public health is very large, each hospital must treat its wastewater until it meets the applicable standard requirements.

Hospital waste has a negative impact on the environment and the surrounding community if it is not managed properly. The effect of hospital waste, namely hospital waste, can be a risk factor for transmitting various diseases such as HIV/AIDS, Hepatitis B and $\mathrm{C}$, and other blood-borne diseases. The US Environmental Protection Agency reports that cases of hepatitis B infection (HBV) due to injury by sharp objects among medical personnel and hospital waste management personnel per year in the US are around 162-321 cases out of a total annual number of 300,000 cases. Meanwhile, in France, there were eight cases of HIV infection, two of which were transmitted through wounds experienced by waste management personnel (A. Pruss et al., 2005:26).

To prevent the issue of environmental pollution and maintain the balance of nature in terms of quantity and quality, it is necessary to have parties who are tasked and responsible for supervising activities that produce waste that is harmful to the environment and its surroundings, as stated in Article 492 paragraph 1 of Government Regulation Number 22 of 2021 concerning Implementation of Environmental Protection and Management which states that "the minister, governor, or regent/mayor is obliged to supervise the compliance of the person in charge of the Business and/or Activity with the stipulated provisions. in Business Licensing or Government Approval related to Environmental Approval and laws and regulations in the field of Environmental Protection and Management". Therefore, waste management activities in hospitals need serious handling through good supervision. Central Sulawesi Province, through the Central Sulawesi Provincial Environmental Service (DLH), has a very important role, namely as a local government institution that has a supervisory function and acts decisively in the management of waste generated by hospitals in its working area. Supervision of hospital waste management is the authority of the DLH Central Sulawesi Province.

The Environmental Service of Central Sulawesi Province has staged the implementation of supervision related to hospital waste management. Before direct supervision of the hospital's business activities, the Central Sulawesi Provincial Environmental Service informs the hospital that monitoring will be carried out. In addition, the Environmental Service of Central Sulawesi Province also has a Standard Operating 
Procedure (SOP) for supervision that must be carried out about its duties as supervisory executor.

Based on interviews with several officials from the Environmental Service of Central Sulawesi Province, the purpose of the supervision was to determine the extent of the hospital's compliance with environmental management regulations. Therefore, as the party anticipating the occurrence of ecological pollution, the Environmental Service of Central Sulawesi Province must always be alert in supervising activities that cause a decrease in the balance of nature both in terms of quantity and quality.

Currently, in Central Sulawesi alone, 19 (nineteen) hospitals must be supervised by the Environmental Service of Central Sulawesi Province, one of which is Undata Palu Hospital. Undata Palu Hospital is included in the list of hospitals supervised by the Environmental Service of Central Sulawesi Province because its location is included in the capital city of Central Sulawesi Province. Undata Palu Regional General Hospital is one of the assets of the Central Sulawesi provincial government that provides health services to people who need health services. Undata Palu Hospital is one of several hospitals managed by the local government and listed as a Type B Hospital. This health service has been registered since 22 February 1979 with license number 445/123/OOT/KP2TD/2011.

The activities carried out at the Undata Hospital Palu are very diverse, so that they produce not only medical waste but also non-medical waste. This waste will be a source of pollution for the surrounding environment and a nuisance to public health. Hospitals must provide waste management facilities and infrastructure so that the waste produced does not cause pollution and endanger the community.

However, from the results of initial observations, researchers found several problems related to the supervision of hospital waste management by the Environmental Service of Central Sulawesi Province. First, the intensity of supervision is still lacking. The Environmental Service carries out routine supervision only once a year to all hospitals, namely. In 2017 the Central Sulawesi Provincial Environmental Service supervised Undata Palu Hospital on Monday, February 13th.

Second, the Environmental Service of Central Sulawesi Province has not been maximal in meeting the existing standard operating procedures (SOP). The Environmental Service of Central Sulawesi Province has standard operating procedures (SOPs) in carrying out supervision, as for the legal basis for monitoring environmental management, including Law Number 32 of 2009 concerning environmental protection and management, Government Regulation Number 41 of 20092009 concerning Control of Air Pollution, Regulation of the Minister of the Environment Number 1 of 2010 concerning the Management of Water Pollution, Regulation of the Minister of the Environment Number 101 of 2014 concerning Management of Hazardous and Toxic Waste, Regulation of the Minister of the
Environment Number 5 of 2014 concerning Wastewater Quality Standards, Regulation of the Minister of Environment and Forestry of the Republic of Indonesia Number P.12 of 2020 concerning Storage of Hazardous and Toxic Waste, until the latest Government Regulation of the Republic of Indonesia Number 22 of 2021 concerning Implementation of Environmental Protection and Management. The SOP requires a sampling tool to test the validity of the data. However, the equipment to test the validity of the data owned by the Environmental Service of Central Sulawesi Province is still inadequate. The Environment Agency of Central Sulawesi Province only has equipment for testing surface water quality and does not yet have equipment for testing wastewater and ambient air. Testing the validity of the data is very important because it proves whether the hospital does not pollute the environment.

Third, there is still a lack of guidance and direction given by the Environmental Service of Central Sulawesi Province. If a hospital does not meet government standards in waste management, the Central Sulawesi Provincial Environmental Service usually provides guidance and direction. The advice and recommendation given are in the form of field practice if a hospital makes mistakes in waste management, but the hospital's guidance and direction are still not felt.

Apart from providing health services, hospitals are also a place that has the most potential as a producer of waste that can harm the environment and humans themselves. These wastes must be managed properly because if they are not handled properly, they will seriously impact the environment and the surrounding community. Sharps waste has a potential hazard and can cause injury through tears or punctures and transmit infectious diseases.

Chemical waste generated from the use of chemicals in medical and laboratory procedures can corrode waterways or explode. Meanwhile, pharmaceutical waste such as expired drugs must be processed so that it is not misused. Based on the description of the various problems above, it can be seen that there are still problems in the implementation of its monitoring activities. Therefore the authors are interested in conducting a study on the Supervision of the Environmental Service of Central Sulawesi Province in Waste Management at Undata Palu Hospital.

\section{LITERATURE REVIEW}

\section{Public Administration Concept}

Public administration has existed since time immemorial; it will emerge in an organized society. In the historical record of human civilization in South Asia, including Indonesia, China, and ancient Egypt, a system of governance has been obtained. The structuring system is now known as public/state administration (Thoha, 2008:88).

Liang Gie (2009:9) says that "administration broadly is a series of activities carried out by a group of people in a collaboration to achieve certain goals." The administration 
broadly explains that a series of activities requiring a cooperative process is not a new thing because it has arisen together with the emergence of human civilization.

Theories in state administration can be traced from the development of the administrative science paradigm itself, which scientists first used to explain the phenomena of scientific development or a perspective to analyze social phenomena that developed in society. And the book by Janet V. Denhardt and Robert B. Denhardt entitled "The New Public Service: Serving, not Steering " can be used to understand the science of administration. Janet V. Denhardt and Robert B. Denhardt divide trying to divide the paradigm of State administration into three major groups, namely the paradigm of The Old Public Administration (OPA), The New Public Management (NPM), and The New Public Service (NPS).

\section{Concept About Management}

In this study, the researcher cites the definition of management according to several experts. According to Hasibuan (2012:1), "is the science and art of regulating the process of utilizing human resources and other resources effectively and efficiently to achieve a certain goal." According to Daft (2012:10), "management is the achievement of organizational goals effectively and efficiently through planning, organizing, leading, and controlling organizational resources."

According to Hasibuan (2012: 56), "management functions are the basic elements that will always exist and are inherent in the management process that will be used as a reference by managers in carrying out activities to achieve goals." According to Siagian (2014: 1), "management functions are the basic elements that will always exist and are inherent in the management process that will be used as a reference by managers in carrying out activities in achieving goals."

Daft (2012:16), "management has four functions, namely planning ( planning), organizing ( organizing), leadership (leading), and controlling (controlling). From these basic management functions, follow-up is then carried out after it is known that what has been determined has been "achieved" or "not achieved." According to Henry Fayol in Safroni (2012: 47), "management functions include planning ( planning), organizing ( organizing), Direction ( commanding), Coordination ( coordinating), Controlling (controlling)." Meanwhile, according to George R. Terry in Hasibuan (2012:68), management functions include planning, organizing, actuating, and controlling.

\section{Supervision Concept}

According to Fahmi, quoted by Erlis (2016: 44), the definition of supervision is that "supervision is generally defined as the way an organization realizes effective and efficient performance, and further supports the realization of the organization's vision and mission." According to Murhaini (2014: 242), he explained that "supervision is an assessment which is a process of measurement and verification of a series of processes that have been carried out on an ongoing basis."

Supervision aims to determine the course of the implementation of tasks and provide an understanding to a certain person or agency about what must be done to know the performance measures in every decision making. The supervision results are expected to achieve the results and standards that have been set so that there are no errors or failures and can immediately take action when deviations occur. According to Danamik in Ihyaul Ulum (2009:129), "one aspect of supervisory activities is the implementation of an examination which is generally defined as a systematic process to identify problems, analyzes and evaluations that are carried out independently and constructively and by giving opinions or if deemed need recommendations."

According to Widodo (2016: 94), "the monitoring strategy is the same as implementation, namely determining who does it, how the SOP is to carry out control, how much budget is needed, the yard is needed and the schedule for the implementation of supervision."

\section{Actors controlling policy implementation}

The actors controlling the implementation of policies can be divided into two types, namely external control, and internal control. The perpetrators of internal control (internal control) can be carried out by the monitoring and control unit or section and the regional supervisory body. External control actors can be carried out by DPRD, NGOs, and community components.

\section{Standard Operational Monitoring}

SOP control over policy implementation can be described as follows:

a. The organization must establish a set of measurable objectives from the planned activities.

b. Monitoring tools should be developed to measure the performance of individuals, programs, or the system as a whole.

c. Measurements can be obtained through the application of various monitoring tools to correct any significant deviations.

d. Corrective action may include efforts to lead to the performance specified in the plan or modification of the project towards approaching performance.

\section{Financial Resources and Equipment}

To exercise control over the implementation of a policy, in addition to requiring sufficient funds, adequate equipment is also required. The amount of the budget and the type of equipment to carry out control are highly dependent on the variety and complexity of implementing a policy. Budget sources can come from the state budget (APBN), regional budget (APBD), non- 
governmental organizations (NGOs) and nongovernmental organizations.

\section{Control Implementation Schedule}

In internal control, the implementation can be done every month, every quarter, or every semester. However, the external control is outside the organization and is not the organization's authority that is the controlling actor to do the scheduling. In addition, external power is difficult to intervene.

\section{Hospital Waste}

One sector that produces hazardous toxic waste is the health sector, namely the hospital, where the hospital is a means of improving health and can also be used as an educational institution for health workers and research. According to Asmadi (2013: 6), "hospital waste or waste is all waste generated by hospital activities and other supporting activities." In addition, Chandra (2012:64) suggests that medical, solid waste is waste directly generated from the act of diagnosis and medical treatment of patients. Medical, solid waste is also known as clinical waste. This clinical waste can be dangerous and cause health problems for visitors, especially for the officers who handle the waste and the community around the hospital. Clinical waste originates from medical, dental, pharmaceutical, or similar services; research, treatment, care, or education that uses toxic, infectious, hazardous, or potentially harmful substances, unless certain precautions are taken.

While medical liquid waste is the liquid waste that contains toxic substances, such as inorganic chemicals, organic substances derived from the washing water of the operating room and autopsy if not managed properly or directly discharged into public sewers, will be very dangerous and can cause unpleasant odors and can pollute the environment (Chandra, 2012: 69).

As one of the public health service facilities, the hospital environment is a gathering place for sick and healthy people to become a place for disease transmission and allows environmental pollution and health problems. To avoid risks and health problems, it is necessary to organize hospital ecological health by implementing waste management according to the requirements and procedures set to protect patients, patient's families, and all health workers in the hospital environment.

Hospital waste management that is not goodwill triggers the risk of work accidents and disease transmission from patients to workers, from patients to patients, from workers to patients, and from and to hospital visitors. Of course, as a socioeconomic institution, because of its task of providing health services to the community, the hospital cannot be separated from managing the waste generated.

\section{RESEARCH METHODS}

The type of research used in this research is descriptive research, using a qualitative approach. This research is located in two places, namely the Environmental Service of Central Sulawesi Province as the agency tasked and responsible for carrying out supervision related to hospital waste management, and Undata Palu Hospital as a place or agency that manages hospital waste.

Informants who act as sources of data and information must meet the requirements; in qualitative research, there is no question about the number of informants, but it can depend on whether or not the selection of informants is appropriate and the complexity of the diversity of social phenomena studied. Due to the location of this research in two places, so that the informants involved in this study were also from the two relevant agencies, which informants from the Environmental Service included: Head of the Environmental Service of Central Sulawesi Province, Head of Environmental Management, Head of Management Section B3 waste, one of the staff of the Environmental Service of Central Sulawesi Province, and the Head of the Development and Supervision Section of the Environmental Service of Palu City.

While the second is Undata Palu Hospital, where the informants from the agency consist of the Head of the Environmental Sanitation Installation, the Coordinator of Liquid Waste Management, and the Coordinator of Solid Waste Management. In addition, in this study, the researchers involved several people who live around the Palu Undata Hospital. As for the technique of determining the informants in this study using the Purposive Sampling technique.

Data was collected through the process of observation, interviews, documentation, and literature study. In this study, the data were analyzed using several steps according to the theory of Miles and Huberman through (1) data collection, (2) data reduction, (2) data display, and (3) conclusion drawing and verification.

\section{RESULTS AND DISCUSSION}

Supervision is a systematic effort to establish implementation standards with planning objectives, design feedback information systems, compare actual activities with predetermined criteria, determine and measure deviations and take necessary corrective actions to ensure that resources are used properly — an effective and efficient way of achieving organizational goals.

Supervision also has a very important meaning for local governments because the existence of supervisory activities will provide improvements in overcoming environmental pollution that occurs and for implementing supervision functions as a form of supervisory Activity, namely contributing to the passage of a development activity so that monitoring activities can be achieved following the stated objectives. Expected to be effective and efficient, as for the supervision activities, namely to ensure that all activities 
carried out in an organization are based on a plan including a predetermined strategy without the need to question at the managerial level where the project is prepared and determined.

Development activities that we know today refer to economic growth to achieve people's welfare. Still, not a small number of the environment has been damaged due to the implementation of these developments, especially medical activities. Medical activities in Palu are one of the many businesses that can pollute the environment, from the ongoing activities that impact the surrounding community, both beneficial and detrimental from these activities. Those damaging to the community require the Environmental Service as a party to be authorized to carry out supervision in any business that has the potential to pollute the environment. The purpose of the supervisory activities carried out by the Environmental Service of Central Sulawesi Province is that the implementation process is carried out following the plan's provisions, take corrective action if there are deviations, and the resulting objectives are following the procedure. In this study, the researcher will describe the discussion of the research results based on the data obtained by the researchers through the results of observations, interviews, and documentation regarding the Supervision of the Environmental Service in Supervising Hospital Waste Management (Case Study at Undata Hospital Palu). This study uses Joko Widodo's Theory of Supervision, which researchers use to analyze which consists of Actors of Policy Implementation Control, Monitoring Operational Standards, Financial Resources and Equipment, and Control Implementation Schedules.

\section{Actors Controlling Policy Implementation}

The actors who control the implementation of policies are divided into two types, namely those that hold external and internal policies. The internal control actors can be carried out by the monitoring and control unit or section and the regional supervisory body. In contrast, the DPRD, NGOs, and community components can carry out the external control actors. Based on researcher interviews with informants, the internal control actor in implementing policies regarding hospital waste management in Palu City, especially Undata Hospital, is the Environmental Service of Central Sulawesi Province.

Supervision of waste management at the Undata Hospital is still under the authority of the Palu City Environmental Service, but that does not mean that the Provincial Environmental Service cannot supervise waste management activities at the hospital, the Provincial Environmental Service can provide recommendations to the City Environment Service to evaluate or verifying issues or reports submitted to the Provincial Environmental Service regarding violations related to environmental management carried out by the Palu Undata Hospital, through which the Palu City Environmental Service can request assistance to carry out field supervision jointly. In addition, the information from the informants above shows that, after the issuance of Government Regulation Number 5 of 2021 concerning the Implementation of RiskBased Business Licensing, the authority to supervise and issue environmental permits is already the authority of the Environmental Service of Central Sulawesi Province to carry out direct supervision without going through the Department of Environment. Palu City Environment, but this is still in the process so that for now, the management is still held by the Palu City Environmental Service.

The supervision of hospital waste management by the Environmental Service of Central Sulawesi Province is carried out by the Environmental Supervisory Officer (PPLH). This is as regulated in Article 1 of Government Regulation Number 22 of 2021, which states that "Functional Environmental Supervisory Officers, in the future, referred to as Supervisory Officers Environment is a civil servant who is given full duties, responsibilities, authority and rights by the authorized official to carry out supervision and enforcement of environmental law. The regulation stipulates that PPLH has full jurisdiction in supervising every Activity that has the potential to damage or pollute the environment, including waste management operations at Undata Hospital.

Impact control can only be carried out through preventive supervision because this supervision shows the existence of checks and balances to avoid the occurrence of the arbitrariness of an institution or institution in carrying out its activities. In supervising hospital waste management, the Environmental Service of Central Sulawesi Province conducts inspections from the administrative aspect to the active part.

The Environment Agency also conducts inspections regarding the completeness of permits, whether the hospital already has an environmental permit, a Temporary Storage (TPS) permit for hazardous waste, and a license for liquid waste management. In addition, his party also examines the documents that explain the state of the business activities. What kind of waste is produced every day, making routine reports, facilities, and infrastructure for managing the hospital's waste and checking whether the waste management is following what is stipulated by government regulations.

The Environmental Service of Central Sulawesi Province, when conducting surveillance activities at the Undata Palu Hospital, usually conducts inspections from viewing documents, asking for manifest waste generated, and controlling B3 Waste TPS. Meanwhile, for the Technical Implementation Unit (UPT) of the laboratory itself, in carrying out supervision, it does sampling.

In carrying out supervisory activities, supervision techniques are also needed so that supervision activities take place effectively. Supervision techniques consist of direct and indirect supervision. Straightforward supervision technique is supervision that is carried out directly to the place where supervision activities will be carried out. In contrast, indirect supervision is carried out remotely, such as through reports, so there is no need to go directly to the place. Article 496 of 
Government Regulation Number 22 of 2021 outlines that supervision can be carried out using direct supervision and indirect supervision. As referred to in paragraph (2), letter a, the direct supervision is carried out by visiting the location of the Business and Activity a. regular or b. incidental. Indirect supervision, as referred to in paragraph (2), letter $b$ is carried out through reviewing the report data of the person in charge of the Business and Activity and data from the Environmental Information System. The Environmental Service of Central Sulawesi Province uses direct supervision techniques in its supervision activities. Still, for supervision at the Palu Undata Hospital, the Central Sulawesi Provincial Environmental Service is waiting for coordination from the Palu City Environmental Service because the supervisory authority, for now, is entirely under the City Environment Service. Palu, so that the Environmental Service of Central Sulawesi Province assists in the supervision if needed. However, in the future, if the environmental permit for Undata Hospital is due, then the permit will be issued by the Environmental Service of Central Sulawesi Province because with the issuance of Government Regulation Number 5 of 2021 , the authority related to environmental licensing for type B hospitals will be transferred to the Environmental Service of Central Sulawesi Province so that this agency will be in full control of ecological supervision in the hospital.

In carrying out supervisory activities, the Environmental Service of Central Sulawesi Province has a certain field which is indeed a special task to carry out supervision. The field that is following its main duties and functions to carry out supervision is the field of environmental management. In the field of environmental management, 14 employees carry out supervisory activities.

There are only 5 employees who carry out supervisory activities. Of course, this amount is still insufficient, so that sometimes when conducting supervision in the field, they are assisted by other areas related to waste, and even then it is still not sufficient, because to carry out supervision, enough human resources are needed to accommodate all activities that need to be monitored for environmental management.

The number of employees in the field of environmental management who carry out supervisory activities is still small. Only one Environmental Supervisory Officer (PPLH) is assisted by several staff when carrying out supervisory activities. Human resources are the most important factor in an organization. They are the main key because human resources are the movers, thinkers, and planners and determine success in achieving goals within the organization. However, the human resources owned by the Environmental Service of Central Sulawesi Province are still limited in terms of quantity because the number of employees is not proportional to the tasks carried out.

The Environmental Service of Central Sulawesi Province is still very limited in PPLH staff and does not yet have a Civil Servant Investigator (PPNS). PPLH and PPNS are experts who are needed in supervising activities. PPLH has full duties, responsibilities, authorities, and rights by the authorized official to carry out environmental monitoring activities. At the same time, PPNS is a certain civil servant official who, based on the law, is appointed as an investigator and has the authority to carry out criminal investigations within the scope of the law. The laws on which they are based.

In addition to the number of human resources, which is an important factor in an organization, it cannot be denied that the quality of human resources must also be considered in achieving the success of an organization's goals. The quantity and quality of human resources must be balanced so that activities in an organization run smoothly and without obstacles. The quality of human resources owned by the Environmental Service of Central Sulawesi Province is still inadequate and limited in carrying out its duties.

The resources in the Environmental Management Sector, whose main function is to carry out supervisory activities, are still limited regarding their educational background. Not all employees in the field whose academic background is not following the tasks they currently carry out.

According to the Indonesian Center for Environmental Law or abbreviated as ICEL (2020), currently, the implementation of supervision still faces classic obstacles, which include, among others, the disproportionate number of competent Environmental Supervisory Officers (PPLH) throughout Indonesia compared to the number of business activities that must be monitored, the lack of data and a history of compliance by business actors as the basis for monitoring and not optimal management of environmental information systems for supervision, and the accountability mechanism for environmental supervision is not yet optimal. These problems make environmental supervision not optimally encourage compliance and, more fundamentally, have not been able to enforce environmental regulations, let alone maintain the environment's good and nutritional quality. However, even though human resources are still very limited, some employees have attended training or training.

\section{Standard Operating Procedures for Supervision}

Standard operating procedures are guidelines or steps used so that the activities of an organization run smoothly - standard operating procedures. Become a reference or guideline for carrying out work tasks following an organization's main functions and functions.

Every institution certainly needs a guide to carry out each task and function of each element of the institution or agency. So it is necessary to have a Standard Operating Procedure (SOP) to facilitate compiling, tidying, and controlling the company's system. SOP contains aspects related to the sequence of the process of doing work from beginning to end. SOP is a rule about procedures carried out in an orderly manner to complete a job and obtain effective work results.

Environmental compliance monitoring activities are one of the efforts in enforcing ecological and forestry laws to determine 
to what extent the level of compliance of Business Actors and Activities in managing the environment follows the provisions of obligations contained in-laws and regulations and environmental permits. This is in line with Article 492 of Government Regulation Number 22 of 2021, which states that (1) The Minister, governor, or regent/mayor are obliged to supervise the compliance of the person in charge of the Business and Activity to the provisions stipulated in the Business Licensing or related Government Approval. Environmental Approval and laws and regulations in the field of Environmental Protection and Management. (2) The supervision, referred to in paragraph (1), is carried out based on the minister's norms, standards, procedures, and criteria.

The Environmental Service of Central Sulawesi Province adheres to several applicable laws and regulations. The Ministry of Environment and Forestry issued the SOP for Supervision of Licensing Compliance and Environmental Management Legislation as a reference in carrying out their duties. SOPs serve as a basis for assessment in case of deviations made by supervisors, directing them to behave in a disciplined manner in supervising, knowing the obstacles quickly, and guiding them in carrying out their supervisory duties.

Environmental Monitoring is part of the environmental law enforcement mechanism at the Ministry of Environment and Forestry. Environmental supervision is needed to determine the extent to which business actors and activities comply with the provisions in ecological permits and conditions in environmental laws and regulations. The environmental supervision regulated in the Standard Operating Procedure (SOP) is identical to the supervisory activities that have been carried out by the Ministry of Environment and Forestry and the agencies responsible for environmental management, both in the Province and in the Regency/City. This Environmental Monitoring SOP was created as a reference for ecological supervision in supervising environmental management facilities and evaluating the administration of ecological management directly in the field (Ministry of Environment and Forestry, 2020).

In carrying out its supervisory duties on waste management, specifically for hospital waste, the Environmental Service of Central Sulawesi Province strives to adhere to the existing SOPs. Every environmental inspector must understand all supervision procedures and data and information collection techniques. The supervision results will be more accurate and can avoid the risk of legal violations due to procedural errors.

The supervisory mechanism that must be carried out by the Environmental Service of Central Sulawesi Province according to its SOP is that before carrying out supervision, the Central Sulawesi Provincial Environmental Office prepares a work plan, prepares an assignment order, and after the Central Sulawesi Provincial Environmental Service approves it, makes an official report before carrying out supervision, which notifies the parties. The company or the owner of the Activity that supervision will be carried out. After that, the Environmental Service of Central Sulawesi Province can carry out surveillance activities by bringing surveillance equipment such as laptops, stationery, cameras, and sampling equipment.

Furthermore, the control tool that becomes the reference for PPLH in carrying out supervision is Government Regulation Number 22 of 2021 concerning Implementation of Environmental Protection and Management, while other instruments such as Minister of Environment Regulation Number 14 of 2021 concerning Waste Management in Waste Banks, Regulation of the Minister of Health of the Republic of Indonesia Number 7 of 2019 concerning Hospital Environmental Health, most recently Circular Letter of the Ministry of Environment and Forestry Number SE.3/MENLHK/PSLB.3/3/2021 concerning Management of B3 Waste and Waste from Handling Corona Virus Disease (COVID-19), and also the Guidelines for Waste Management of Referral Hospitals, Emergency Hospitals and Health Centers that Handle Covid-19 Patients issued by the Ministry of Health are used as supporting instruments in the implementation of waste management supervision in hospitals. The existence of such a control means that the supervision carried out by PPLH can have the power to encourage compliance with the environmental obligations of business actors that are independent of the consideration of the level of obedience of business actors to commitments outside the environmental sector. This independence of environmental supervision is important because the impact of non-compliance with environmental obligations can lead to ecological disasters. Moreover, environmental damage or pollution can interfere with health and even the safety of human life.

\section{Financial Resources and Equipment}

To exercise control over the implementation of a policy, in addition to requiring sufficient funds, adequate equipment is also required. The size of the budget and the type of equipment to exercise control highly depend on the variety and complexity of implementing a policy. Budget sources can come from the state budget (APBN), regional budget (APBD), non-governmental organizations (NGOs) and nongovernmental organizations. The funding used by the Environment Agency of Central Sulawesi Province comes from the APBD. However, the budget source owned by the Environmental Service of Central Sulawesi Province is still not optimal. Still, with this inadequate budget, the Central Sulawesi Provincial Environmental Service continues to maximize monitoring activities.

In addition to the budget, equipment in monitoring activities is also important to support supervisory activities. The equipment owned by the Environmental Service of Central Sulawesi Province in supporting monitoring activities is still inadequate. The study results indicate that for facilities and infrastructure, the Environmental Service of Central Sulawesi Province is still having problems because its employees still 
use their means of transportation and operational vehicles are still limited. In addition, laboratory equipment to test the validity of the data is still inadequate.

\section{Control Implementation Schedule}

The schedule for implementing control is a monitoring planning scheme that is structured to be then carried out following the plan. This control is implemented regularly and repeatedly to keep the object or Activity being supervised in the proper procedure. To conduct environmental management, especially waste, the Environment Agency refers to Government Regulation Number 22 of 2021 concerning the Implementation of Environmental Protection and Management, which in Article 496 states that supervision can be carried out through direct and indirect supervision. Then it is continued in the article explaining that the direct supervision as intended is carried out by visiting the location of the Business and Activity on a regular or incidental basis. Regular supervision is carried out on a scheduled basis. Incidental supervision is not the case because incidental supervision is only carried out if there are issues or reports related to waste management violations carried out by businesses or activities carried out in the community. Article 497 explains that regular supervision, referred to in Article 496, is carried out following the annual plan based on business permits or government approvals related to environmental approvals and other information. This indicates that regular supervision must be implemented on a scheduled basis as a preventive effort in overcoming ecological pollution due to activities or activities from businesses or medical service activities such as hospitals.

The study results indicate that the Environmental Service has routinely carried out the implementation of waste management supervision. The performance of this supervision is carried out every year. Preventive control is a preventative measure taken before an emergency, loss, or problem occurs. It can be interpreted that preventive control is controlling the system in advance before the process starts by applying harmful things to enter the system, so that it is designed to prevent errors or deviations from occurring, for example, supervision is carried out only when pollution or waste spills are detrimental to the local community. Preventive supervision is also very clearly regulated in Article 1 of Government Regulation Number 22 of 2021, which in the regulation reads: "Control of Marine Pollution and/or Damage is every effort or activity to prevent and/or control and/or recover Marine Pollution and/or Marine Damage."

However, lately, the implementation of regular supervision cannot be carried out optimally, where the management is not routinely carried out even in the last three years the Environmental Service has never again visited the hospital, only reports in the form of documents on the implementation of environmental management are used as a referral for the Environment Agency in monitoring the hospital's performance in managing its waste. This happened not without reason after the disaster that hit Palu City at the end of 2018 made the implementation of supervision unable to be carried out maximally. The activities of institutions, both hospitals and the Environmental Service, were still focused on improving the agency's facilities and infrastructure.

\section{CONCLUSIONS}

Based on the results of the study, it can be concluded that the supervision of hospital waste management by the Central Sulawesi Environmental Service has not run optimally, this is due to the limited number of human resources and the competence possessed by the supervisory officers from the Central Sulawesi Environmental Service is still little. The Environment Agency of Central Sulawesi has socialization activities regarding the procedures for environmental pollution complaints, but the socialization activities are still not fully felt by the community. This is also the cause of community participation in monitoring and preventing environmental pollution is still low, and there are still people who do not know where to make complaints.

In terms of the equipment owned by the Central Sulawesi Environmental Service, the laboratory equipment for testing the validity of the data is still incomplete and operational vehicles are still limited in number and the lack of budget owned by the Central Sulawesi Environmental Service because each year the budget obtained is still minimal.

Schedule The implementation of control carried out by the Central Sulawesi Environmental Service is still not optimal, where in the last three years, regular (scheduled) monitoring has no longer been carried out, only reports in the form of documents on the implementation of environmental management are used as a reference for the Environment Agency in monitoring The performance of hospitals in managing their waste, this happened because after the disaster that hit Palu City at the end of 2018 ago, the implementation of supervision could not be carried out maximally, because the activities of institutions, both hospitals and the Environmental Service, were still focused on improving the facilities and infrastructure of the agency.

\section{REFERENCES}

[1] Asmadi. 2013. Pengelolaan Limbah Medis Rumah Sakit. Yogyakarta: Goysen Publishing.

[2] Chandra, B. 2012. Pengantar Kesehatan Lingkungan. Jakarta: EGC

[3] Daft, Richard L. 2012. Manajemen, Edisi Kelima Jilid Satu. Jakarta: Erlangga.

[4] Departemen Kesehatan Republik Indonesia. 2006. Pedoman pencegahan dan pengendalian infeksi di rumah sakit dan fasilitas pelayanan kesehatan lainnya. Jakarta: Depkes RI.

[5] Erlis Milta Rin Sondole. 2016. Pengaruh Disiplin Kerja, Motivasi dan Pengawasan terhadap Kinerja Karyawan pada PT. Pertamina (Persero) Unit Pemasaran VII Pertamina BBM Bitung. Jurnal EMBA, Volume 3 Nomor 3.

[6] Hasibuan, Malayu S.P. 2012. Manajemen: Dasar, Pengertian, dan Masalah. Jakarta: PT. Bumi Aksara.

[7] Ihyaul, Ulum. 2009. Pengawasan Sektor Publik: Suatu Pengantar. Jakarta. PT. Bumi Aksara.

[8] Indonesian Center For Environmental Law. 2020. Penguatan Sistem Pengawasan Lingkungan Hidup. 
[9] Keptusan Menteri Kesehatan Republik Indonesia Nomor 7 Tahun 2019 tentang Kesehatan Lingkungan Rumah Sakit.

[10] Miles, M.B, Huberman, A.M, dan Saldana, J. 2014. Qualitative Data Analysis, A Methods Sourcebook, Edition 3. USA: Sage Publications. Terjemahan Tjetjep Rohindi Rohidi. Jakarta: UIPress.

[11] Murhaini, Suriansyah. 2014. Manajemen Pegawasan Pemerintahan Daerah. Yogyakarta: Pustaka Pelajar.

[12] Pedoman Pengelolaan Limbah Rumah Sakit Rujukan, Rumah Sakit Darurat Dan Puskesmas Yang Menangani Pasien Covid-19. 2020. Pengelolaan Air Limbah Pengelolaan Limbah Padat Domestik Pengelolaan Limbah B3 Medis Padat. Kementerian Kesehatan Republik Indonesia.

[13] Peraturan Pemerintah Republik Indonesia Nomor 101 Tahun 2014 tentang Pengelolaan Limbah Bahan Berbahaya dan Beracun.

[14] Peraturan Menteri Lingkungan Hidup Dan Kehutanan Republik Indonesia Nomor P.12 Tahun 2020 tentang Penyimpanan Limbah Bahan Berbahaya Dan Beracun.

[15] Peraturan Pemerintah Republik Indonesia Nomor 22 Tahun 2021 tentang Penyelenggaraan Perlindungan dan Pengelolaan Lingkungan Hidup.

[16] Pruss, A. dkk. 2005. Pengelolaan Aman Limbah Layanan Kesehatan. Jakarta: Penerbit Buku Kedokteran EGC.

[17] Safroni, Ladzi. 2012. Manajemen Dan Reformasi Pelayanan Publik Dalam Konteks Birokrasi Indonesia. Surabaya: Aditya Media Publishing.

[18] Samsul. 2016. Paradigma Administrasi Publik. Dalam https://samsulaldi.wordpress.com.

[19] Siagian, Sondang, P. 2014. Manajemen Sumber Daya Manusia. Jakarta: Bumi Aksara.

[20] Silalahi, Ulbert. 2005. Studi Tentang Ilmu Administrasi Konsep, Teori dan Dimensi. Bandung: Sinar Baru Algensindo.

[21] Soemirat J. 2014. Kesehatan Lingkungan. Yogyakarta: Gadjah Mada University Press.

[22] Surat Edaran Kementerian Lingkungan Hidup dan Kehutanan Nomor SE.3/MENLHK/PSLB.3/3/2021 tentang Pengelolaan Limbah B3 dan Sampah Dari Penanganan Corona Virus Disease (COVID-19)

[23] The Liang, Gie. 2009. Ensiklopedia Administrasi. Jakarta: Gunung Agung.

[24] Thoha, Miftah. 2008. Ilmu Administrasi Public Kontemporer. Jakarta: Kencana.

[25] Widodo, Joko. 2016. Analisis Kebijakan Publik. Malang: Mayumedia Publishing. 